ISSN 1392-3196 / e-ISSN 2335-8947

Zemdirbyste-Agriculture, vol. 106, No. 1 (2019), p. 21-28

DOI 10.13080/z-a.2019.106.003

\title{
Macro and trace elements in oat cultivars bred in Latvia
}

\author{
Ida JAKOBSONE${ }^{1}$, Sanita ZUTE², Mara BLEIDERE ${ }^{2}$, Inara KANTANE ${ }^{3}$, Lidija ECE ${ }^{1,2}$, \\ Vadims BARTKEVICS ${ }^{4}$
}

\author{
${ }^{1}$ Department of Chemistry, University of Latvia \\ Jielgavas 1, Riga, Latvia \\ E-mail: ida.jakobsone@lu.lv \\ ${ }^{2}$ Stende Research Centre, Institute of Agricultural Resources and Economics (AREI) \\ Dižstende, Libagu parish, Talsu distr., Latvia
}

${ }^{3}$ Faculty of Business, Management and Economics, University of Latvia

Aspazijas 5, Riga, Latvia

${ }^{4}$ Institute of Food Safety, Animal Health and Environment (BIOR)

Lejupes 3 Riga, Latvia

\begin{abstract}
The aim of the research was to quantify 13 macro and trace elements in different oat (Avena sativa L.) genotypes depending on the year of cultivation (2011, 2012 and 2013) and crop management practice (conventional or organic), agronomic practice (different $\mathrm{N}$ supply) and evaluate the risks regarding $\mathrm{Cd}, \mathrm{Pb}, \mathrm{Cr}, \mathrm{Ni}, \mathrm{Cu}, \mathrm{Zn}$ and $\mathrm{Al}$ concentrations and nutritional aspects regarding $\mathrm{K}, \mathrm{Na}, \mathrm{Ca}, \mathrm{Mn}, \mathrm{Mg}, \mathrm{Fe}, \mathrm{Cu}, \mathrm{Zn}$ and $\mathrm{Cr}$ concentrations in oat grain. Elements $\mathrm{Cd}, \mathrm{Pb}$, $\mathrm{Cr}$, $\mathrm{Ni}$ and $\mathrm{Al}$ were detected by electrothermal atomic absorption spectrometry, and $\mathrm{K}, \mathrm{Na}, \mathrm{Zn}, \mathrm{Cu}, \mathrm{Ca}, \mathrm{Mg}, \mathrm{Mn}$ and Fe were analysed by flame atomic absorption spectrometry. Cluster analysis showed that genotype and agronomic / crop management practice play an important role in the concentration of macro and trace elements in oat grain. Statistically different concentrations of elements were noticed for $\mathrm{Cr}, \mathrm{Ni}, \mathrm{Zn}, \mathrm{K}$ and $\mathrm{Mg}$ among the genotypes: for $\mathrm{Mn}$ and $\mathrm{Fe}$ in grains, grown conventionally or organically, for $\mathrm{Cr}, \mathrm{Ni}, \mathrm{Zn}, \mathrm{K}$ and $\mathrm{Mg}$ in hulled and naked grain, and for $\mathrm{Cd}, \mathrm{Pb}, \mathrm{Ni}$, $\mathrm{Cu}, \mathrm{Al}, \mathrm{K}, \mathrm{Na}$ and $\mathrm{Mg}$ among the study years. The concentrations of potentially hazardous elements were low: $\mathrm{Cd}$ $0.008-0.023, \mathrm{~Pb} 0.014-0.060$, Cr 0.117-1.460, Ni 0.447-1.834, Cu 3.2-4.1 and $\mathrm{Zn} 22.0-32.3 \mathrm{mg} \mathrm{kg}^{-1}$. Oat products can contribute to the consumption of necessary macro and trace elements, especially of $\mathrm{Mn}, \mathrm{Mg}$ and Fe: $30.0-49.3$, 1166-1486 and 33.5-48.9 $\mathrm{mg} \mathrm{kg}^{-1}$, respectively, as well as Cr and Zn.
\end{abstract}

Key words: Avena sativa, conventional farming, macro and trace elements, nutritional aspects, organic agriculture, risk assessment, statistical indicators.

\section{Introduction}

Cereal products are included in the base of food pyramid. They provide significant amounts of nutrients and minerals, and therefore are important for balanced diet. According to Poutanen (2012), the average annual consumption of cereals in the European Union (EU) is $131 \mathrm{~kg}$ per capita. Human consumption of oats is rather low. According to the EU Cereals balance sheet for marketing year 2016-2017, the human use of oats in EU countries is 1.1 million tonnes, from the total use of 8.2 million tonnes (EU, 2017).

Due to their particular biochemical composition, oats are considered as ideally suited for the production of healthy products (Martínez-Villaluenga, Peñas, 2017). Whole grains of oats are rich in dietary fibres and therefore are an excellent raw material for healthy foods. The consumption of oats in Nordic and Baltic countries is rather low compared to wheat; however, in Latvia this figure has increased during the last decades (Sahlstrom, Knutsen, 2010). According to FAOSTAT data (FAOSTAT, 2017, http://faostat.fao.org), Latvia has one of the highest consumption of oats in the world
(7.0 kg per capita), followed by Denmark $(5.0 \mathrm{~kg}$ per capita) and Finland (4.0 kg per capita), Lithuania $(3.0 \mathrm{~kg}$ per capita) and Estonia (2.0 kg per capita). In the EU, human consumption of oats is $2.8 \mathrm{~kg}$ per capita, which is 3.5 times higher than that of barley.

The prerequisite for the production of high quality foodstuffs is a high quality raw material - grain. The results of studies on oats in Latvia confirmed that grain quality indices can be affected by the weather conditions during the growing season, location and genotypes (Bleidere et al., 2012), meteorological conditions (Zute et al., 2010) and nitrogen management (Brunava et al., 2015). Therefore development of oat cultivars adaptable to changing climatic conditions and capable of ensuring both stable yields and corresponding grain quality from year to year is the most significant task for oat breeders in Latvia. In the last decade, oat researchers from the AREI have worked in several research projects to clarify which oat cultivars should be recommended for growing in Latvia and which technological elements ought to be applied in oat cultivation to satisfy the requirements of 
both farmers and processors of oats. The investigation of chemical composition of cultivars and promising breeding lines is the priority of food oat research (Sterna et al., $2015 \mathrm{a}$ ).

Naked, less creatively called "hull-less oats", lose their hulls in the field, returning nutrients directly to the soil. They can be rolled without any industrial heat treatment, giving raw, unprocessed and naturally tasty product. The naked oat is now becoming more wide-spread in Latvia because of the opportunity for its different uses. Naked oats are used by small processors to produce a wide range of niche products. 'Stendes Emilija', included in this study, is the first local naked oat cultivar registered in Latvia. Other studies showed that grains of naked cultivars have an excellent biochemical composition - high levels of soluble fibres such as betaglucan (Brunava et al., 2015), crude protein (Sterna et al., 2016) and high content of $\alpha$-tocopherol (Sterna et al., 2014 ) - traits, determining dietary quality of products.

In breeding of cereal cultivars it is important to pay attention both to the characteristics essential for the processing industry and the ability of the cultivars to adapt to the growing conditions. Nitrogen $(\mathrm{N})$ is the most limiting nutrient for cereal production; therefore adoption of good $\mathrm{N}$ management strategies often results in significant economic benefits to farmers. In the breeding process it is important to identify genotypes providing high productivity and ensuring grain quality at lower $\mathrm{N}$ rates. Organic farming system is best placed to respond to the challenges of effective nitrogen management (Hirel et al., 2011). It was found that chemical composition of oat grain such as content of proteins and amino acids, $\beta$-glucans, lipids, $\alpha$-tocopherol and total dietary fibres can fluctuate due to different $\mathrm{N}$ levels and crop management practices (conventional or organic) applied (Vilmane et al., 2015; Sterna, 2015 b).

From the nutritional point of view, attention is mainly focused on essential macro elements $(\mathrm{K}, \mathrm{Ca}$ and $\mathrm{Mg}$ ) and trace elements $(\mathrm{Fe}, \mathrm{Cu}, \mathrm{Mn}$ and $\mathrm{Zn}$ ) in grain products. Minerals in cereal grain are mostly found in the aleurone layer (Lui et al., 2007; Poutanen, 2012). Mineral and vitamin deficiencies affect a greater number of the world's population than does protein energy malnutrition. Even though these micronutrients are needed in a minute quantities (i.e. micrograms to milligrams per day), they have a tremendous impact on human health and wellbeing. Insufficient dietary intakes of these nutrients impair the functions of brain, immune and reproductive systems and energy metabolism (Graham et al., 2001; Teklić et al., 2013).

Some of the trace elements, including $\mathrm{Fe}, \mathrm{Mg}$, $\mathrm{Zn}$ and $\mathrm{Co}$, are essential micronutrients for biochemical functions in all living organisms. However, the benefits of these micronutrients may be completely reversed at too high concentrations. Some heavy metals, particularly $\mathrm{Cd}$ and $\mathrm{Pb}$, have been considered as serious soil and environment pollutants due to their toxicity at low concentrations (Korkmaz et al., 2010).

The concentration and influence on human health of toxic heavy metals $(\mathrm{Pb}, \mathrm{Cd}$ and $\mathrm{Cr})$ and essential heavy metals $(\mathrm{Ni}, \mathrm{Cu}$ and $\mathrm{Zn}$ ) in agricultural products was briefly analysed in the articles of Pirsaheb et al. (2015) and Teklić et al. (2013). Pb and Cd have been characterized as very toxic even at low concentrations, $\mathrm{Cr}$ is a carcinogen, but it is essential at low concentrations, $\mathrm{Ni}$ can be toxic, but normally occurs at very low concentrations, $\mathrm{Zn}$ and $\mathrm{Cu}$ are needed for human organism.

Zinc ( $\mathrm{Zn}$ ) deficiency causes growth failure and weakened immunity in young children. It also is linked to a higher risk of diarrhoea and pneumonia, resulting in nearly 800,000 deaths per year (World Food Programme,
2017, https://www.wfp.org/hunger/malnutrition/types). Aluminium $(\mathrm{Al})$ is sometimes mentioned as a harmful element too. According to WHO (1996), tolerable daily intake of $\mathrm{Al}$ is $1 \mathrm{mg}$.

The aim of the research was to determine the concentration of 13 macro and trace elements in different oat genotypes depending on the year of cultivation (2011, 2012 and 2013), crop management practice (conventional or organic) and agronomic practice (different $\mathrm{N}$ supply), and evaluate risks regarding $\mathrm{Cd}, \mathrm{Pb}, \mathrm{Cr}, \mathrm{Ni}, \mathrm{Cu}, \mathrm{Zn}$ and $\mathrm{Al}$ concentration and nutritional aspects regarding $\mathrm{K}, \mathrm{Na}$, $\mathrm{Ca}, \mathrm{Mn}, \mathrm{Mg}, \mathrm{Fe}, \mathrm{Cu}, \mathrm{Zn}$ and $\mathrm{Cr}$ concentration in oat grain.

\section{Materials and methods}

Description of experimental conditions. Field trials were carried out during 2011-2013 at the Institute of Agricultural Resources and Economics (AREI),

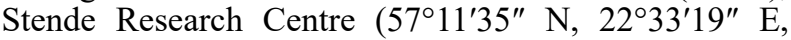
$78 \mathrm{~m}$ a. s. 1.), Latvia under conventional and organic crop management systems.

Organic field trials. Trials were arranged in the organically certified fields. The soil type was Stagnic Retisol (loamic), content of organic matter was $20.2-21.6 \mathrm{mg} \mathrm{kg}^{-1}, \mathrm{pH}_{\mathrm{KCl}} 5.27-5.89$, the content of plant-available phosphorus $\left(\mathrm{P}_{2} \mathrm{O}_{5}\right)-138-164 \mathrm{mg} \mathrm{kg}^{-1}$ and potassium $\left(\mathrm{K}_{2} \mathrm{O}\right)-130-175 \mathrm{mg} \mathrm{kg}^{-1}$. The common organic management practices were used during the vegetation period.

Conventional field trials. The soil type in the conventional field was Stagnic Retisol (loamic), content of organic matter 21-24 mg kg-1 $\mathrm{pH}_{\mathrm{KCl}} \mathrm{s} 5.4-5.8$, available phosphorus $\left(\mathrm{P}_{5} \mathrm{O}_{5}\right)-137.0-158.8 \mathrm{mg} \mathrm{kg}^{-1}$ and potassium $\left(\mathrm{K}_{2} \mathrm{O}\right)-175.7-211.0 \mathrm{mg} \mathrm{kg}{ }^{-1}$. Soil characteristics met the requirements for oat cultivation. The experimental treatment consisted of three mineral nitrogen $(\mathrm{N})$ rates - N80, N120 and N160 in the conventional growing conditions. Complex mineral fertilizer was used as a basic fertilizer at the rate $725 \mathrm{~kg} \mathrm{ha}^{-1}(\mathrm{~N}-80, \mathrm{P}-28.6$, $\left.\mathrm{K}-112.4 \mathrm{~kg} \mathrm{ha}^{-1}\right)$. Nitrogen was split-applied at sowing and at the end of tillering stage (GS 29) of the crop. Ammonium nitrate (N 34\%) was used as top-fertilizer: $40 \mathrm{~kg}$ of $\mathrm{N}$ per ha (N120) and $80 \mathrm{~kg}$ of N per ha (N160). The treatments were laid out in a randomized complete block design with four replicates, he plot size was $10 \mathrm{~m}^{2}$.

Weather conditions. The average air temperature from April to August differed annually (Table 1). The most significant differences $(p<0.05)$ in temperature were noticed in June, it varied from $13^{\circ} \mathrm{C}(2012)$ to $17^{\circ} \mathrm{C}$ (2011 and 2013), while similar temperature in all study years was in August (from 15.5 to $16.6^{\circ} \mathrm{C}$ ). Rainfall differences between the study years were most significant $(p<0.05)$ in July - it ranged from $36(2013)$ to $165 \mathrm{~mm}$ (2011). The weather conditions were warmer than the long term average (norm) with occasional heavy rainfalls during the growing period of 2011.

Description of the studied oats. In cooperation with the AREI Stende Research Centre the following oat (Avena sativa L.) cultivars or genotypes from oat breeding program were used in the research: hulled 'Lizete' and naked 'Stendes Emilija' (in previous publications breeding line S-156) and naked breeding line No. 33793 ('Nos nacht' / 'Stmara'). 'Lizete' is one of the newest oat cultivars bred in Latvia characterized by specific plant morphological traits suitable for growing in crop mixtures. From the dietary point of view, under Latvian conditions 'Lizete' grain showed heightened content of soluble dietary fibre (Sterna et al., 2016). Both naked genotypes had particularly high protein (Vilmane et al., 2015) and $\alpha$-tocopherol content (Sterna et al., 2014). 
Table 1. The average monthly air temperatures and sum of precipitation (Stende, Latvia, 2011-2013)

\begin{tabular}{|c|c|c|c|c|c|c|c|c|}
\hline \multirow{2}{*}{ Month } & \multicolumn{4}{|c|}{ Average air temperature ${ }^{\circ} \mathrm{C}$} & \multicolumn{4}{|c|}{ Sum of precipitation $\mathrm{mm}$} \\
\hline & 2011 & 2012 & 2013 & norm & 2011 & 2012 & 2013 & norm \\
\hline April & 6.9 & 5.6 & 4.0 & 4.3 & 26.8 & 42.7 & 34.9 & 37 \\
\hline May & 10.6 & 11.0 & 13.7 & 10.2 & 54.7 & 58.9 & 86.1 & 45 \\
\hline June & 16.8 & 13.2 & 16.9 & 14.2 & 59.6 & 78.7 & 74.5 & 57 \\
\hline July & 19.2 & 17.5 & 16.9 & 16.3 & 165.3 & 91.7 & 36.2 & 87 \\
\hline August & 16.3 & 15.5 & 16.6 & 15.5 & 155.0 & 115.1 & 45.2 & 87 \\
\hline Average & 14.0 & 12.6 & 13.6 & 12.1 & 92.3 & 77.4 & 55.3 & 62.6 \\
\hline
\end{tabular}

Oat genotypes were sown with a plot seeder 'Hege 80' (Germany) in a well prepared seedbed at a rate of 500 viable seeds per $\mathrm{m}^{2}$. The plot size was $10 \mathrm{~m}^{2}$, four replicates. The grain was harvested by a combine harvester 'Hege 140'. Sampling procedure was done according to the ISO 950 Cereals-Sampling (as grain).

Analysis of macro and trace elements. Thirteen macro and trace elements $(\mathrm{Cd}, \mathrm{Pb}, \mathrm{Ni}, \mathrm{Cr}, \mathrm{Al}, \mathrm{Cu}, \mathrm{K}$, $\mathrm{Na}, \mathrm{Mn}, \mathrm{Fe}, \mathrm{Zn}, \mathrm{Mg}$ and $\mathrm{Ca}$ ) were analysed in the cereal grain samples $(\mathrm{n}=36)$, provided by the Stende Research Centre and collected during the period of 2011-2013.

Sample mineralization. Grains were ground and $0.5-1.0 \mathrm{~g}$ was weighed into the crucible. The crucible was placed into the muffle furnace with a programmable heating. Grain samples were dried for $1 \mathrm{~h}$ at $110^{\circ} \mathrm{C}$; then the temperature was increased $\left(50^{\circ} \mathrm{C} \mathrm{h}^{-1}\right)$ to $450^{\circ} \mathrm{C}$ and maintained for eight hours. After that the crucible was removed from the muffle furnace and cooled to room temperature, and 1-3 $\mathrm{ml}$ of water was added to the dry residue. This procedure was repeated until light grey or white ash was obtained. Then $2 \mathrm{ml} 6 \mathrm{M}$ hydrogen chloride $(\mathrm{HCl})$ was added and evaporated. The residue was dissolved in 25 ml $0.1 \mathrm{M}$ nitric acid ( $\mathrm{HNO}_{3}$ ) (AOAC, 1999 - Determination of lead, cadmium, copper, iron and zinc in foods. Atomic absorption spectrophotometry after dry ashing). The obtained solutions were used for element detection.

Sample analysis. Five elements $(\mathrm{Cd}, \mathrm{Cr}, \mathrm{Al}$, $\mathrm{Pb}$ and $\mathrm{Ni}$ ) were detected by electrothermal atomic absorption spectrometry (ETAAS) with Zeeman background correction (Perkin Elmer AAnalyst 600, USA) after dry digestion, and eight elements ( $\mathrm{K}, \mathrm{Na}$, $\mathrm{Zn}, \mathrm{Cu}, \mathrm{Ca}, \mathrm{Mg}, \mathrm{Mn}$ and $\mathrm{Fe}$ ) were detected by flame atomic absorption spectrometry (FAAS) (Perkin Elmer AAnalyst 800, USA).

Quality assurance. Analytical performance of the applied procedure was checked by the intra laboratory validation procedure in accordance with the Commission Regulation (EC) No. 333/2007. Relative standard deviation $<20 \%$ and accuracy within the interval $70-115 \%$ was obtained for all elements measured within the current research. Quantification limits of the applied analytical procedure varied between $0.005 \mathrm{mg} \mathrm{kg}^{-1}(\mathrm{Cd})$ and $1 \mathrm{mg} \mathrm{kg}^{-1}(\mathrm{~K}$ and $\mathrm{Na})$. In addition, the analytical procedure has been successfully checked (z-score below 2) by participation in the proficiency testing rounds organized by the European Union Reference Laboratory.

Human exposure and nutritional value assessment. Calculation of use of grain and grain products in Latvia was done using the data of the Central Statistical Bureau of Latvia about consumption of flour, dough, flakes, bread, pasta, pizza, pastry, etc. per capita in 2015 (CSB, 2015). The calculated human consumption was $\sim 130 \mathrm{~g}$ per day per capita. To assess the potential health risk from intake of potentially harmful elements $(\mathrm{Cd}, \mathrm{Cr}, \mathrm{Pb}, \mathrm{Ni}, \mathrm{Cu}, \mathrm{Zn}$ and $\mathrm{Al})$ the values of estimated weekly intake (EWI) were calculated using the formula from ATSDR (2005) in modified version used by Reinholds et al. (2017):

$$
\mathrm{EWI}=\mathrm{C} \times 130 \times \frac{\mathrm{T}}{60},
$$

where EWI is exposure dose in $\mu \mathrm{g} \mathrm{kg}^{-1}$ per week per $\mathrm{kg}$ of body weight, $\mathrm{C}$ - element concentration $\mathrm{mg} \mathrm{kg}^{-1}$ grain, 130 - human intake of grain products g per capita per day, T - 7 days per week and 60 - theoretical weight of human body $60 \mathrm{~kg}$. The results were compared with published data and recommendations.

Statistical analysis. The data were processed using the software IBM SPSS Statistics for Windows, version 22.0 (IBM Corp., USA). For data analysis the following methods were used: descriptive statistics indicators of central tendency or location and indicators of variability, non-parametric statistics - Kruskal-Wallis test, pairwise comparisons with Bonferroni correction and Mann-Whitney test.

\section{Results and discussion}

Concentration of macro and trace elements in oat genotypes depending on agronomic / crop management practice. Concentrations of macro and trace elements in three oat genotypes depending on agronomic practice (conventional growing with three different nitrogen rates) and organic practice are shown in Table 2 (macro elements) and Table 3 (trace elements). The highest and lowest average concentrations for each element are marked in bold, and no visible regularities were noticed. In many cases a standard deviation was very high.

Potassium (K). The highest $\mathrm{K}$ concentration was in No. $33793+\mathrm{BIO}$ and 'Stendes Emilija' + BIO samples $\left(4307 \mathrm{mg} \mathrm{kg}^{-1}\right)$, the lowest - in 'Lizete' +160 $\left(3277 \mathrm{mgkg}^{-1}\right)$. The distribution of $\mathrm{K}$ concentration differed statistically significantly in oat genotypes (Kruskal-Wallis test, $p=0.023$ ). The $\mathrm{K}$ concentration differed statistically significantly in No. 33793 and 'Lizete' (pairwise comparisons with Bonferroni correction $p=0.018$ ).

Sodium $(\mathrm{Na})$. The highest $\mathrm{Na}$ concentration was in 'Lizete' + 120 sample $\left(171 \mathrm{mg} \mathrm{kg}^{-1}\right)$, the lowest - in No. $33793+120$ sample $\left(29 \mathrm{mg} \mathrm{kg}^{-1}\right)$. The distribution of $\mathrm{Na}$ concentration did not differ statistically significantly between the oat genotypes (Kruskal-Wallis test, $p=0.088$ ).

Calcium $(\mathrm{Ca})$. The highest $\mathrm{Ca}$ concentration was in No. $33793+160$ sample $\left(835 \mathrm{mg} \mathrm{kg}^{-1}\right)$, the lowest - in 'Lizete' + BIO sample $\left(664 \mathrm{mg} \mathrm{kg}^{-1}\right)$. The distribution of Ca concentration did not differ statistically significantly between the genotypes (Kruskal-Wallis test, $p=0.521$ ).

Magnesium (Mg). The highest $\mathrm{Mg}$ concentration was in No. 33793+ 80 sample $\left(1486 \mathrm{mg} \mathrm{kg}^{-1}\right)$, the lowest in 'Lizete' + BIO sample (1166 $\left.\mathrm{mg} \mathrm{kg}^{-1}\right)$. The distribution of $\mathrm{Mg}$ concentration differed statistically significantly in oat genotypes (Kruskal-Wallis test, $p<0.0005$ ). The $\mathrm{Mg}$ concentration differed statistically significantly in No. 33793 and 'Lizete', 'Stendes Emilija' and 'Lizete' (pairwise comparisons with Bonferroni correction $p=0.002, p<0.0005$, respectively).

Iron $(\mathrm{Fe})$. The highest $\mathrm{Fe}$ concentration was in 'Lizete' + 160 sample (48.9 $\left.\mathrm{mg} \mathrm{kg}^{-1}\right)$, the lowest - in 'Stendes Emilija' + BIO sample ( $\left.33.5 \mathrm{mg} \mathrm{kg}^{-1}\right)$. The distribution of $\mathrm{Fe}$ concentration did not differ statistically significantly between the genotypes (Kruskal-Wallis test, $p=0.501$ ).

Cadmium $(C d)$. The highest $\mathrm{Cd}$ concentration was in 'Stendes Emilija' +120 sample $\left(0.023 \mathrm{mg} \mathrm{kg}^{-1}\right)$, the lowest - in 'Stendes Emilija' + BIO sample $\left(0.008 \mathrm{mg} \mathrm{kg}^{-1}\right)$. The distribution of $\mathrm{Cd}$ concentration did not differ statistically significantly between the genotypes (Kruskal-Wallis test, $p=0.986$ ). 
Table 2. The concentration ( $\mathrm{mg} \mathrm{kg}^{-1}$ ) of macro elements in oat grain depending on the agronomic / crop management practice

\begin{tabular}{|c|c|c|c|c|c|c|c|c|c|}
\hline \multirow{2}{*}{$\begin{array}{l}\text { Ele- } \\
\text { ment }\end{array}$} & \multirow{2}{*}{$\begin{array}{c}\text { Sample of } \\
\text { oat grain }\end{array}$} & \multicolumn{2}{|c|}{$\begin{array}{c}\text { Conventional, } \\
\text { N80 }\end{array}$} & \multicolumn{2}{|c|}{$\begin{array}{c}\text { Conventional, } \\
\text { N120 }\end{array}$} & \multicolumn{2}{|c|}{$\begin{array}{c}\text { Conventional, } \\
\text { N160 }\end{array}$} & \multicolumn{2}{|c|}{ Organic } \\
\hline & & $\bar{x} \pm \mathrm{SD}$ & range & $\bar{x} \pm \mathrm{SD}$ & range & $\bar{x} \pm \mathrm{SD}$ & range & $\bar{x} \pm \mathrm{SD}$ & range \\
\hline \multirow{3}{*}{ K } & No. 33793 & $4072 \pm 320$ & 4440 & $299 \pm 327$ & 40 & $091 \pm 285$ & $92-4360$ & $307 \pm 428$ & 17 \\
\hline & , & 4004 & & \pm 272 & & $3 \pm 361$ & $3740-4460$ & \pm 18 & \\
\hline & & $3659 \pm 756$ & & $=825$ & & \pm 695 & 41 & & \\
\hline \multirow{3}{*}{$\mathrm{Na}$} & & & & & & \pm 30 & & \pm 32 & \\
\hline & & & & & & \pm 46 & & & \\
\hline & & & & & & \pm 89 & & 131 & \\
\hline \multirow{3}{*}{$\mathrm{Ca}$} & & 824 & & $=221$ & 1- & \pm 346 & $591-$ & \pm 180 & 98 \\
\hline & ilija' & $787 \pm 199$ & 6. & $6 \pm 335$ & $3-$ & \pm 211 & $633-$ & $770 \pm 179$ & 971 \\
\hline & & $698 \pm 118$ & & 222 & & $=254$ & 630 & 247 & 47 \\
\hline \multirow{3}{*}{$\mathrm{Mg}$} & s & $1407 \pm 126$ & $1278-1529$ & $12 \pm 102$ & $1303-1504$ & $1393 \pm 108$ & $1304-1513$ & $1517 \pm 87$ & $1454-1616$ \\
\hline & 'Stendes Emilija' & $1486 \pm 90$ & $1394-1573$ & $1472 \pm 147$ & $1311-1600$ & $1481 \pm 142$ & $1348-1630$ & $1458 \pm 101$ & $1365-156$ \\
\hline & & $1191 \pm 149$ & 1071 & $1259 \pm 53$ & $1227-$ & $1276 \pm 92$ & $1209-1381$ & $1166 \pm 85$ & 233 \\
\hline \multirow{3}{*}{$\mathrm{Fe}$} & & $44.2 \pm 3.0$ & 42.0 & $8 \pm 1.4$ & $45.0^{-}$ & $44.5 \pm 4.4$ & $41.0-49.4$ & $36.5 \pm 3.5$ & $33.0-40.0$ \\
\hline & 'Stendes Emilija' & $45.2 \pm 2.0$ & $43.0-47.0$ & $46.5 \pm 1.9$ & $45.0-48.6$ & $48.0 \pm 3.6$ & $44.0-51.0$ & $33.5 \pm 5.1$ & $28.0-38.0$ \\
\hline & 1260 & $44.0 \pm 8.6$ & $35.0-52.0$ & $48.7 \pm 6.3$ & $45.0-56.0$ & $48.9 \pm 9.6$ & $40.0-59.0$ & $41.2 \pm 10.4$ & $33.6-53.0$ \\
\hline
\end{tabular}

Note. $\mathrm{N} 80-$ mineral N rate $80 \mathrm{~kg} \mathrm{ha}^{-1}, \mathrm{~N} 120-$ mineral N rate $120 \mathrm{~kg} \mathrm{ha}^{-1}, \mathrm{~N} 160-$ mineral N rate $160 \mathrm{~kg} \mathrm{ha}^{-1}$; average value $\pm \mathrm{SD}$ and range presents results from the year 2011, 2012 and 2013; bold - highest and lowest average concentrations for particular element.

Table 3. The concentration $\left(\mathrm{mg} \mathrm{kg}^{-1}\right)$ of trace elements in oat grain depending on agronomic / crop management practice

\begin{tabular}{|c|c|c|c|c|c|c|c|c|c|}
\hline \multirow{2}{*}{$\begin{array}{l}\text { Ele- } \\
\text { ment }\end{array}$} & \multirow{2}{*}{$\begin{array}{c}\text { Sample of } \\
\text { oat grain }\end{array}$} & \multicolumn{2}{|c|}{$\begin{array}{c}\text { Conventional, } \\
\text { N80 }\end{array}$} & \multicolumn{2}{|c|}{$\begin{array}{c}\text { Conventional, } \\
\text { N120 }\end{array}$} & \multicolumn{2}{|c|}{$\begin{array}{c}\text { Conventional, } \\
\text { N160 }\end{array}$} & \multicolumn{2}{|c|}{ Organic } \\
\hline & & $\bar{x} \pm \mathrm{SD}$ & range & $\bar{x} \pm \mathrm{SD}$ & range & $\bar{x} \pm \mathrm{SD}$ & range & $\bar{x} \pm \mathrm{SD}$ & range \\
\hline \multirow{3}{*}{$\mathrm{Cd}$} & No. 33793 & $0.014 \pm 0.010$ & $.005-0.024$ & $023 \pm 0.022$ & $.005-0.0$ & $021 \pm 0.0$ & $.005-0.0$ & $012 \pm 0.0$ & $0.005-0.0$ \\
\hline & 'Stendes & $0.014 \pm 0.013$ & $<0.005-0.029$ & $\mathbf{0 . 0 2 3} \pm \mathbf{0 . 0 2 0}$ & $0.009-0.046$ & $0.021 \pm 0.018$ & $<0.005-0.040$ & $\mathbf{0 . 0 0 8} \pm \mathbf{0 . 0 0 3}$ & $<0.005-0.010$ \\
\hline & 'Lizete' & $.010 \pm 0.004$ & $<0.005-0.013$ & $0.018 \pm 0.018$ & $<0.005-0$ & $0.020 \pm 0.014$ & $<0.005-0.031$ & $0.013 \pm 0.0$ & 10 \\
\hline \multirow{3}{*}{$\mathrm{Pb}$} & No. 33793 & $0.060 \pm 0.079$ & $<0.010-$ & $0.027 \pm 0.030$ & 800100 & $0.027 \pm 0.030$ & $<0.010-0$. & 00010 & 2 \\
\hline & $\begin{array}{l}\text { 'Stendes } \\
\text { Emilija' }\end{array}$ & 5 & 0 & 0 & 7 & 8 & $<0$ & 7 & 24 \\
\hline & 'Lizete' & $027 \pm 0.017$ & $<0.01$ & \pm 0.021 & $<0.01$ & \pm 0.016 & 0.02 & 0.02 & - \\
\hline \multirow{3}{*}{$\mathrm{Cr}$} & No. 33793 & $240 \pm 0.043$ & 0.192 & $64 \pm 0.052$ & $0.111-$ & $0.140 \pm 0.041$ & $0.095-0.176$ & $0.227 \pm 0.036$ & .262 \\
\hline & $\begin{array}{l}\text { 'Stendes } \\
\text { Emilija' }\end{array}$ & 37 & 0.12 & 1 & 76 & 0. & 0.218 & 078 & 0.076 \\
\hline & & 45 & 0 & 175 & 0.64 & \pm 1.181 & 70 & 1 & 10 \\
\hline \multirow{3}{*}{$\mathrm{Ni}$} & No. & \pm 0.279 & 0.298 & $900 \pm 0.785$ & 0.274 & $0.864 \pm 0.497$ & $0.439-1.410$ & $0.620 \pm 0.406$ & $\overline{040}$ \\
\hline & $\begin{array}{l}\text { 'Stendes } \\
\text { Emiliia' }\end{array}$ & $0.989 \pm 0.398$ & $0.568-1.360$ & $0.845 \pm 0.483$ & $0.471-1.390$ & $0.815 \pm 0.378$ & $0.434-1.190$ & $0.447 \pm 0.260$ & -0.687 \\
\hline & & $=0.570$ & 0.70 & \pm 0.769 & 0.85 & 0.854 & 0.85 & & 0. \\
\hline \multirow{3}{*}{$\mathrm{Cu}$} & No. & $4.0 \pm 0.7$ & $3.5-4.8$ & \pm 0.5 & $3.7-4.7$ & $3.9 \pm 0.9$ & $3.1-4$. & 0.4 & \\
\hline & $\begin{array}{l}\text { 'Stendes } \\
\text { Emilija' }\end{array}$ & \pm 0.2 & 3.2 & 0.5 & 2 & $36+04$ & 8 & $3.2 \pm 0.6$ & $28,-3$ \\
\hline & 'Lizete' & & & & & & & & \\
\hline \multirow{3}{*}{$\mathrm{Zn}$} & No. 33793 & $26.8 \pm 3.0$ & $24.0-30.0$ & $28.9 \pm 1.1$ & $27.8-30.0$ & $31.1 \pm 2.9$ & $28.3-34.0$ & $29.7 \pm 6.5$ & $23.0-36.0$ \\
\hline & $\begin{array}{l}\text { 'Stendes } \\
\text { Emilija' }\end{array}$ & $29.6 \pm 5.5$ & $25.9-36.0$ & 1.0 & $26.0-28.0$ & $32.3 \pm 6.5$ & $26.0-39.0$ & $313+46$ & $26.0-34.0$ \\
\hline & 'Lizete' & & & & & & & & \\
\hline \multirow{3}{*}{$\mathrm{Al}$} & No. 33793 & $14 \pm 7.78$ & $0.77-15.06$ & $7 \pm 5.85$ & 0.63 & $5.86 \pm 7.10$ & $0.68-13.95$ & \pm 6.56 & 12.50 \\
\hline & $\begin{array}{l}\text { 'Stendes } \\
\text { Emilija' }\end{array}$ & 2.94 & $1.06-6.82$ & 3. & $2-6.28$ & 3.03 & $1.01-7.06$ & 86 & -11.40 \\
\hline & 'Lizete' & & & .15 & 1.0 & 71 & & & \\
\hline \multirow{3}{*}{$\mathrm{Mn}$} & No. 33793 & $36.0 \pm 8.7$ & 30. & $5 \pm 3.9$ & $41.0-48$. & $1 \pm 3.7$ & $46.0-52.4$ & $32.0 \pm 7.9$ & $26.0-40.9$ \\
\hline & $\begin{array}{l}\text { 'Stendes } \\
\text { Emiliia' }\end{array}$ & 35.8 & $26.0-44.3$ & $46.1 \pm 9.0$ & $36.0-53.4$ & $49.0 \pm 7.8$ & $40.0-53.9$ & $31.6 \pm 9.0$ & $25.0-41.9$ \\
\hline & 'Lizete' & 5.6 & 48.0 & 10.4 & 54.3 & 4.5 & $45.0-53.9$ & $30.1 \pm 4.5$ & $25.0-33.3$ \\
\hline
\end{tabular}

Note. $\mathrm{N} 80$ - mineral N rate $80 \mathrm{~kg} \mathrm{ha}^{-1}, \mathrm{~N} 120$ - mineral N rate $120 \mathrm{~kg} \mathrm{ha}^{-1}, \mathrm{~N} 160$ - mineral $\mathrm{N}$ rate $160 \mathrm{~kg} \mathrm{ha}^{-1}$; average value $\pm \mathrm{SD}$ and range presents results from the year 2011, 2012 and 2013; bold - highest and lowest average concentrations for particular element.

Lead $(\mathrm{Pb})$. The highest $\mathrm{Pb}$ concentration was in No. $33793+80$ sample $\left(0.060 \mathrm{mg} \mathrm{kg}^{-1}\right)$, the lowest - in 'Stendes Emilija' +160 sample $\left(0.014 \mathrm{mg} \mathrm{kg}^{-1}\right)$. The distribution of $\mathrm{Pb}$ concentration did not differ statistically significantly between the genotypes (Kruskal-Wallis test, $p=0.802$ ).

Chromium $(\mathrm{Cr})$. The highest $\mathrm{Cr}$ concentration was in 'Lizete' + BIO sample $\left(1.460 \mathrm{mg} \mathrm{kg}^{-1}\right)$, the lowest - in 'Stendes Emilija' + 120 sample $\left(0.117 \mathrm{mg} \mathrm{kg}^{-1}\right)$. The distribution of $\mathrm{Cr}$ concentration differed statistically significant between oat genotypes (Kruskal-Wallis test, $p<0.0005)$. The $\mathrm{Cr}$ concentration differed statistically significantly in No. 33793 and 'Lizete', 'Stendes Emilija' and 'Lizete' (pairwise comparisons with Bonferroni correction $p<0.0005, p=0.001$, respectively).

Nickel (Ni). The highest Ni concentration was in 'Lizete' +160 sample $\left(1.834 \mathrm{mg} \mathrm{kg}^{-1}\right)$, the lowest in 'Stendes Emilija' + BIO sample $\left(0.447 \mathrm{mg} \mathrm{kg}^{-1}\right)$. The distribution of $\mathrm{Ni}$ concentration differed statistically 
significantly between the genotypes (Kruskal-Wallis test, $p=0.007)$. The Ni concentration differed statistically significantly in No. 33793 and 'Lizete', 'Stendes Emilija' and 'Lizete' (pairwise comparisons with Bonferroni correction $p=0.014, p=0.025$, respectively).

Copper $(\mathrm{Cu})$. The highest $\mathrm{Cu}$ concentration was in No. $33793+120$ sample $\left(4.1 \mathrm{mg} \mathrm{kg}^{-1}\right)$, the lowest in 'Stendes Emilija' + BIO sample $\left(3.2 \mathrm{mg} \mathrm{kg}^{-1}\right)$. The distribution of $\mathrm{Cu}$ concentration did not differ statistically significantly between the genotypes (Kruskal-Wallis test, $p=0.096$ ).

Zinc $(\mathrm{Zn})$. The highest $\mathrm{Zn}$ concentration was in 'Stendes Emilija' + 160 sample (32.3 $\left.\mathrm{mg} \mathrm{kg}^{-1}\right)$, the lowest - in'Lizete' +80 sample $\left(22.0 \mathrm{mg} \mathrm{kg}^{-1}\right)$. The distribution of $\mathrm{Zn}$ concentration differed statistically significantly in the genotypes (Kruskal-Wallis test, $p=0.039$ ). The $\mathrm{Zn}$ concentration differed statistically significantly in 'Stendes Emilija' and 'Lizete' (pairwise comparisons with Bonferroni correction $p=0.05)$.

Aluminium $(A l)$. The highest $\mathrm{Al}$ concentration was in 'Lizete' + 120 sample $\left(7.27 \mathrm{mg} \mathrm{kg}^{-1}\right)$, the lowest in 'Lizete' +80 sample $\left(2.32 \mathrm{mg} \mathrm{kg}^{-1}\right)$. The distribution of $\mathrm{Al}$ concentration did not differ statistically significantly between the genotypes (Kruskal-Wallis test, $p=0.833$ ).

Manganese $(\mathrm{Mn})$. The highest $\mathrm{Mn}$ concentration was in 'Lizete' +160 sample $\left(49.3 \mathrm{mg} \mathrm{kg}^{-1}\right)$, the lowest in 'Lizete' +80 sample $\left(30.0 \mathrm{mg} \mathrm{kg}^{-1}\right)$. The distribution of Mn concentration did not differ statistically significantly between the genotypes (Kruskal-Wallis test, $p=0.971$ ).

Concentration of macro and trace elements in oat grain as influenced by conventional or organic cultivation. The statistical indicators of the concentration of macro and trace elements in oat grain depending on crop management practice are reflected in Table 4 Higher $\mathrm{Cd}, \mathrm{Pb}, \mathrm{Ni}, \mathrm{Cu}, \mathrm{Ca}, \mathrm{Mn}$ and $\mathrm{Fe}$ concentrations were observed in the oat grain grown conventionally.

Table 4. The concentration $\left(\mathrm{mg} \mathrm{kg}^{-1}\right)$ of trace and macro elements in oat grain as influenced by conventional and organic crop management practice

\begin{tabular}{ccc}
\hline & $\begin{array}{c}\text { Conventional } \\
\text { (with different N supply) } \\
(\mathrm{n}=27)\end{array}$ & $\begin{array}{c}\text { Organic } \\
(\mathrm{n}=9)\end{array}$ \\
\hline $\mathrm{Cd}$ & $0.018 \pm 0.015$ & $0.011 \pm 0.006$ \\
$\mathrm{~Pb}$ & $0.033 \pm 0.032$ & $0.021 \pm 0.015$ \\
$\mathrm{Cr}$ & $0.549 \pm 0.754$ & $0.613 \pm 0.993$ \\
$\mathrm{Ni}$ & $1.080 \pm 0.622$ & $0.821 \pm 0.669$ \\
$\mathrm{Cu}$ & $3.70 \pm 0.59$ & $3.60 \pm 0.55$ \\
$\mathrm{Zn}$ & $27.91 \pm 4.4$ & $29.2 \pm 4.9$ \\
$\mathrm{Al}$ & $4.97 \pm 4.92$ & $5.11 \pm 5.32$ \\
$\mathrm{~K}$ & $3913 \pm 512$ & $3950 \pm 439$ \\
$\mathrm{Na}$ & $70.9 \pm 78.6$ & $88.8 \pm 91.7$ \\
$\mathrm{Ca}$ & $784 \pm 212$ & $747 \pm 188$ \\
$\mathrm{Mn}$ & $42.8^{*} \pm 10.0$ & $31.2^{*} \pm 6.4$ \\
$\mathrm{Mg}$ & $1375 \pm 141$ & $1380 \pm 181$ \\
$\mathrm{Fe}$ & $46.2^{*} \pm 4.8$ & $37.1^{*} \pm 6.9$ \\
\hline
\end{tabular}

Note. ${ }^{*}-p<0.003$; average value $\pm \mathrm{SD}$ presents results from the years 2011, 2012 and 2013.

The variability of $\mathrm{Cd}, \mathrm{Pb}, \mathrm{Ca}$ and $\mathrm{Mn}$ concentration in the conventionally grown oat grain was higher than in the organically grown grain. The average concentration of $\mathrm{Mn}$ and $\mathrm{Fe}$ differed statistically significantly in the organically and conventionally (with different N supply) grown oats, which was proved by the results of the MannWhitney test $(p<0.003)$. Higher $\mathrm{Cr}, \mathrm{Zn}, \mathrm{Al}, \mathrm{K}, \mathrm{Na}$ and $\mathrm{Mg}$ concentrations were revealed in the organically grown grain, the variability of $\mathrm{Cr}$ and $\mathrm{Al}$ concentrations was. The average concentration of $\mathrm{Cd}, \mathrm{Pb}, \mathrm{Cr}, \mathrm{Ni}, \mathrm{Cu}, \mathrm{Zn}, \mathrm{Al}, \mathrm{K}$, $\mathrm{Na}, \mathrm{Ca}$ and $\mathrm{Mg}$ did not differ statistically significantly in the organically and conventionally (with different $\mathrm{N}$ supply) grown oat grain (Mann-Whitney test, $p>0.176$ ).
Concentration of macro and trace elements in hulled and naked oat grain. Higher $\mathrm{Cr}, \mathrm{Ni}, \mathrm{Cu}, \mathrm{Al}, \mathrm{Na}$ and $\mathrm{Fe}$ concentrations were in hulled grains ('Lizete'), the concentrations of $\mathrm{Cd}, \mathrm{Pb}, \mathrm{Zn}, \mathrm{K}, \mathrm{Ca}, \mathrm{Mn}$ and $\mathrm{Mg}$ were higher in naked grain (No. 33793 and 'Stendes Emilija') (Table 5). The concentration of $\mathrm{Cr}, \mathrm{Ni}, \mathrm{Zn}, \mathrm{K}, \mathrm{Na}$ and $\mathrm{Mg}$ differed statistically significantly in hulled and naked grain, which was proved by results of Mann-Whitney test $(p=0.000, p=0.001, p=0.010, p=0.024, p=0.049$ and $p=0.000$, respectively).

Table 5. The concentration $\left(\mathrm{mg} \mathrm{kg}^{-1}\right)$ of trace and macro elements in the grain of naked and hulled oats

\begin{tabular}{ccc}
\hline & $\begin{array}{c}\text { Naked oats: No. 33793, } \\
\text { 'Stendes Emilija' } \\
(\mathrm{n}=24)\end{array}$ & $\begin{array}{c}\text { Hulled oats } \\
\text { 'Lizete' } \\
(\mathrm{n}=12)\end{array}$ \\
\hline $\mathrm{Cd}$ & $0.017 \pm 0.015$ & $0.015 \pm 0.011$ \\
$\mathrm{~Pb}$ & $0.031 \pm 0.035$ & $0.029 \pm 0.018$ \\
$\mathrm{Cr}$ & $0.186^{* *} \pm 0.098$ & $1.324^{* *} \pm 1.049$ \\
$\mathrm{Ni}$ & $0.762^{*} \pm 0.423$ & $1.521^{* *} \pm 0.699$ \\
$\mathrm{Cu}$ & $3.64 \pm 0.57$ & $3.73 \pm 0.60$ \\
$\mathrm{Zn}$ & $29.6^{*} \pm 4.1$ & $25.5^{*} \pm 3.9$ \\
$\mathrm{Al}$ & $4.83 \pm 4.74$ & $5.34 \pm 5.53$ \\
$\mathrm{~K}$ & $4086^{*} \pm 298$ & $3594^{*} \pm 631$ \\
$\mathrm{Na}$ & $51.5^{*} \pm 39.1$ & $123.1^{*} \pm 118.2$ \\
$\mathrm{Ca}$ & $794 \pm 210$ & $734 \pm 194$ \\
$\mathrm{Mn}$ & $40.5 \pm 9.5$ & $38.7 \pm 12.5$ \\
$\mathrm{Mg}$ & $1453^{*} \pm 105$ & $1223^{* *} \pm 98$ \\
$\mathrm{Fe}$ & $43.0 \pm 5.7$ & $45.7 \pm 8.3$ \\
\hline
\end{tabular}

Note. ${ }^{*}-p<0.05 ; * *-p<0.001$; average value \pm SD presents results from the years 2011, 2012 and 2013

Concentration of macro and trace elements in oat grain depending on year of cultivation and crop management practice. The concentration of $\mathrm{Cd}, \mathrm{Pb}, \mathrm{Ni}$, $\mathrm{Cu}, \mathrm{Al}, \mathrm{K}, \mathrm{Na}$ and $\mathrm{Mg}$ in oat grains between the study years varied statistically significantly (Kruskal-Wallis test, $p<0.016)$ - the concentration range of elements is wide, which means that the weather conditions (air temperature and rainfall, Table 1) had an influence on it (Table 6). The distributions of $\mathrm{Cd}$ and $\mathrm{Na}$ concentrations differed statistically significantly in 2011 and 2013, 2012 and 2013 (pairwise comparisons with Bonferroni correction $p<0.01$ and $p<0.0005$, respectively). The distribution of $\mathrm{Pb}, \mathrm{Ni}$ and $\mathrm{Ca}$ concentrations differed statistically significantly in 2011 and 2012, 2011 and 2013 (pairwise comparisons with Bonferroni correction $p<0.010$ and $p<0.020$, respectively). The distribution of Al concentration differed statistically significantly in all years $(p<0.014)$. The distributions of $\mathrm{Cu}$ and $\mathrm{K}$ concentration differed statistically significantly in 2011 and 2012, 2012 and 2013 (pairwise comparisons with Bonferroni correction $p<0.031$ and $p<0.034$, respectively). The distribution of $\mathrm{Mn}$ and $\mathrm{Mg}$ concentrations differed statistically significantly in 2012 and 2013 (pairwise comparisons with Bonferroni correction $p<0.016)$.

Comparison with the data from other countries. The mean and median data for all 36 oat samples, as well as main literature data regarding the data from different regions are reflected in Tables 7 and 8. In many cases, the concentrations of elements in oat grain samples from different regions are similar to our data. In some cases, the differences are significant. For example, samples from the United Kingdom (UK) contain significantly lower concentrations of $\mathrm{Cd}, \mathrm{Pb}, \mathrm{Cr}$ and $\mathrm{Ni}$, and higher concentrations of $\mathrm{Cu}$ (Chapell et al., 2017). Samples from East regions of Turkey have higher concentrations of $\mathrm{Cu}$ and $\mathrm{K}$ (Dembiras, 2005), in samples from Poland the content of $\mathrm{Na}$ is significantly lower (Rybicka, Gliszczyńska-Świgło, 2017) than in our samples. 
Table 6. The concentration $\left(\mathrm{mg} \mathrm{kg}^{-1}\right)$ of trace and macro elements in oat grain in 2011, 2012 and 2013 as influenced by the conventional and organic crop management practice

\begin{tabular}{|c|c|c|c|c|c|c|}
\hline & $\begin{array}{c}\text { Conventional with } \\
\text { different mineral } \\
\mathrm{N} \text { rates } \\
(\mathrm{n}=9)\end{array}$ & $\begin{array}{l}\text { Organic } \\
(\mathrm{n}=3)\end{array}$ & $\begin{array}{c}\text { Conventional with } \\
\text { different mineral } \\
\mathrm{N} \text { rates } \\
(\mathrm{n}=9)\end{array}$ & $\begin{array}{l}\text { Organic } \\
(\mathrm{n}=3)\end{array}$ & $\begin{array}{c}\text { Conventional with } \\
\text { different mineral } \\
\mathrm{N} \text { rates } \\
(\mathrm{n}=9)\end{array}$ & $\begin{array}{l}\text { Organic } \\
(\mathrm{n}=3)\end{array}$ \\
\hline & \multicolumn{2}{|c|}{2011} & \multicolumn{2}{|c|}{2012} & \multicolumn{2}{|c|}{2013} \\
\hline & $\bar{x} \pm \mathrm{SD}$ & $\bar{x} \pm \mathrm{SD}$ & $\bar{x} \pm \mathrm{SD}$ & $\bar{x} \pm \mathrm{SD}$ & $\bar{x} \pm \mathrm{SD}$ & $\bar{x} \pm \mathrm{SD}$ \\
\hline $\mathrm{Cd}$ & $0.035 \pm 0.012$ & $0.015 \pm 0.006$ & $0.014 \pm 0.006$ & $0.012 \pm 0.003$ & $0.005 \pm 0.002$ & $0.005 \pm 0.000$ \\
\hline $\mathrm{Pb}$ & $0.068 \pm 0.037$ & $0.036 \pm 0.019$ & $0.019 \pm 0.008$ & $0.018 \pm 0.007$ & $0.012 \pm 0.006$ & $0.010 \pm 0.000$ \\
\hline $\mathrm{Cr}$ & $0.324 \pm 0.249$ & $0.288 \pm 0.134$ & $0.973 \pm 1.187$ & $1.194 \pm 1.746$ & $0.350 \pm 0.266$ & $0.356 \pm 0.337$ \\
\hline $\mathrm{Ni}$ & $1.565 \pm 0.536$ & $1.216 \pm 0.635$ & $0.941 \pm 0.734$ & $0.767 \pm 0.982$ & $0.734 \pm 0.097$ & $0.481 \pm 0.110$ \\
\hline $\mathrm{Cu}$ & $4.02 \pm 0.87$ & $3.67 \pm 0.75$ & $3.34 \pm 0.26$ & $3.20 \pm 0.20$ & $3.72 \pm 0.19$ & $3.92 \pm 0.45$ \\
\hline $\mathrm{Zn}$ & $29.7 \pm 3.9$ & $29.3 \pm 5.7$ & $28.22 \pm 5.9$ & $28.7 \pm 6.4$ & $25.8 \pm 1.9$ & $29.6 \pm 4.5$ \\
\hline $\mathrm{Al}$ & $10.60 \pm 4.51$ & $12.12 \pm 0.62$ & $3.40 \pm 1.06$ & $2.09 \pm 1.16$ & $0.90 \pm 0.22$ & $1.13 \pm 0.30$ \\
\hline $\mathrm{K}$ & $3696 \pm 509$ & $3677 \pm 506$ & $4166 \pm 646$ & $4327 \pm 402$ & $3877 \pm 216$ & $3847 \pm 109$ \\
\hline $\mathrm{Na}$ & $123.6 \pm 106.8$ & $130.3 \pm 83.1$ & $75.1 \pm 43.1$ & $123.0 \pm 117.1$ & $13.9 \pm 1.0$ & $12.9 \pm 2.9$ \\
\hline $\mathrm{Ca}$ & $1057 \pm 113$ & $971 \pm 28$ & $625 \pm 68$ & $626 \pm 151$ & $669 \pm 25$ & $643 \pm 68$ \\
\hline $\mathrm{Mn}$ & $40.6 \pm 9.4$ & $29.7 \pm 2.1$ & $37.4 \pm 10.8$ & $25.3 \pm 0.6$ & $50.4 \pm 3.9$ & $38.7 \pm 4.7$ \\
\hline $\mathrm{Mg}$ & $1351 \pm 124$ & $1331 \pm 227$ & $1285 \pm 112$ & $1392 \pm 212$ & $1490 \pm 111$ & $1418 \pm 169$ \\
\hline $\mathrm{Fe}$ & $43.1 \pm 3.7$ & $38.3 \pm 1.5$ & $48.0 \pm 6.4$ & $38.0 \pm 13.2$ & $47.5 \pm 2.0$ & $34.9 \pm 1.5$ \\
\hline
\end{tabular}

Table 7. Comparison of the concentrations of macro elements $\left(\mathrm{mg} \mathrm{kg}^{-1}\right)$ in oat grain and oat product samples from different regions

\begin{tabular}{|c|c|c|c|c|c|c|}
\hline Sample & $\mathrm{K}$ & $\mathrm{Na}$ & $\mathrm{Ca}$ & $\mathrm{Mg}$ & $\mathrm{Fe}$ & Reference \\
\hline Latvia, mean \pm SD & $3922 \pm 489$ & $75 \pm 81$ & $774 \pm 204$ & $1377 \pm 150$ & $43.9 \pm 6.6$ & This research \\
\hline Latvia, median & 3956 & 53 & 690 & 1373 & 45.0 & This research \\
\hline UK, Orkney & $4431 \pm 373$ & $117 \pm 17$ & $508 \pm 49$ & $1099 \pm 35$ & $40.2 \pm 3.4$ & Chapell et al., 2017 \\
\hline UK, Berwik & $4107 \pm 315$ & $41 \pm 16$ & $552 \pm 70$ & $960 \pm 85$ & $34.4 \pm 5.3$ & Chapell et al., 2017 \\
\hline Finland, oat flakes & 3900 & - & 430 & 1300 & 32 & Ekholm et al., 2007 \\
\hline Finland, oat bran & 5500 & - & 630 & 2110 & 61 & Ekholm et al., 2007 \\
\hline Turkey, East & $18400 \pm 2100$ & - & $1200 \pm 400$ & $1600 \pm 500$ & $26.4 \pm 2.4$ & Demirbas, 2005 \\
\hline Sweden, hulled & - & $44 \pm 20$ & $461 \pm 32$ & - & $49 \pm 10$ & Xin-Zhong et al., 2014 \\
\hline Denmark, hulled & - & $42 \pm 16$ & $529 \pm 142$ & - & $38 \pm 8$ & Xin-Zhong et al., 2014 \\
\hline China, naked & - & $200 \pm 88$ & $520 \pm 178$ & - & $29 \pm 9$ & Xin-Zhong et al., 2014 \\
\hline $\begin{array}{l}\text { Polish market, } \\
\text { oat flour }\end{array}$ & $3510 \pm 40$ & $4 \pm 1$ & \pm 22 & $1330 \pm 40$ & $54.9 \pm 1.1$ & $\begin{array}{l}\text { Rybicka, Gliszczyńska- } \\
\text { Świgło, } 2017\end{array}$ \\
\hline $\begin{array}{l}\text { Polish market, } \\
\text { oat flakes }\end{array}$ & $3210 \pm 110$ & $<0.1$ & $344 \pm 16$ & $1210 \pm 20$ & $48.5 \pm 2.1$ & $\begin{array}{l}\text { Rybicka, Gliszczyńska- } \\
\text { Świgło, } 2017\end{array}$ \\
\hline
\end{tabular}

Table 8. Comparison of the concentrations of trace elements $\left(\mathrm{mg} \mathrm{kg}^{-1}\right)$ in oat grain and oat product samples from different regions

\begin{tabular}{|c|c|c|c|c|c|c|c|c|c|}
\hline Sample & $\mathrm{Cd}$ & $\mathrm{Pb}$ & $\mathrm{Cr}$ & $\mathrm{Ni}$ & $\mathrm{Cu}$ & $\mathrm{Zn}$ & $\mathrm{Al}$ & $\mathrm{Mn}$ & Reference \\
\hline Latvia, mean $\pm \mathrm{SD}$ & $\begin{array}{c}0.016 \pm \\
0.013\end{array}$ & $\begin{array}{c}0.030 \pm \\
0.029\end{array}$ & $\begin{array}{c}0.565 \pm \\
0.805\end{array}$ & $\begin{array}{l}1.015 \pm \\
0.635\end{array}$ & $3.7 \pm 0.6$ & $28.2 \pm 4.4$ & $\begin{array}{c}5.003 \pm \\
4.944\end{array}$ & $39.9 \pm 10.5$ & This research \\
\hline Latvia, median & 0.011 & 0.195 & 0.225 & 0.815 & 3.7 & 27.9 & 3.190 & 41.5 & This research \\
\hline UK, Orkney & n.a. & n.a & $<0.02$ & $<0.02$ & $44.8 \pm 4.4$ & $21.2 \pm 5.5$ & - & $35.3 \pm 0.2$ & Chapell et al., 2017 \\
\hline UK, Berwik & n.a. & n.a. & $<0.02$ & $<0.02$ & $40.6 \pm 19$ & $20.5 \pm 5.5$ & - & $41.1 \pm 6.9$ & Chapell et al., 2017 \\
\hline Finland, oat flakes & 0.02 & 0.05 & - & 1.39 & 4 & 33 & 6 & 45 & Ekholm et al., 2007 \\
\hline Finland, oat bran & 0.03 & 0.05 & - & 1.86 & 5 & 43 & 4 & 57 & Ekholm et al., 2007 \\
\hline Turkey, East & - & - & - & - & $14.8 \pm 1.3$ & $26.4 \pm 2.1$ & - & $16.9 \pm 1.7$ & Demirbas, 2005 \\
\hline Sweden, hulled & - & - & - & - & - & $29 \pm 2.7$ & - & - & Xin-Zhong et al., 2014 \\
\hline Denmark, hulled & - & - & - & - & - & $29 \pm 6$ & - & - & Xin-Zhong et al., 2014 \\
\hline China, naked & - & - & - & - & - & $32 \pm 8$ & - & - & Xin-Zhong et al., 2014 \\
\hline $\begin{array}{l}\text { Polish market, } \\
\text { oat flour }\end{array}$ & - & - & - & - & $4.4 \pm 0.4$ & $30.3 \pm 0.6$ & - & $37.2 \pm 1.2$ & $\begin{array}{l}\text { Rybicka, Gliszczyńska- } \\
\text { Świgło, } 2017\end{array}$ \\
\hline $\begin{array}{l}\text { Polish market, } \\
\text { oat flakes }\end{array}$ & - & - & - & - & $3.5 \pm 0.1$ & $30.5 \pm 1.2$ & - & $36.8 \pm 1.6$ & $\begin{array}{l}\text { Rybicka, Gliszczyńska- } \\
\text { Swigło, } 2017\end{array}$ \\
\hline
\end{tabular}

n.a. - negligible amount

Risk assessment and nutritional aspects regarding element concentration in oats. To evaluate the health risk regarding $\mathrm{Cd}, \mathrm{Pb}, \mathrm{Cr}, \mathrm{Ni}, \mathrm{Cu}$ and $\mathrm{Zn}$ concentrations in oat grain, the mean concentrations were used for all 36 samples (Table 9). The estimated weekly intake (EWI) was calculated presuming that all weekly consumption of grain $\left(130 \mathrm{~g} \mathrm{day}^{-1}\right.$ per 7 days $)$ consists of oat products. Such approach seems acceptable as in the article of Jākobsone et al. (2015) it has been shown that the concentration of heavy elements is low in all grain species grown in Latvia and used for human consumption.

The calculated values of EWI were compared with PTWI of $\mathrm{Cr}, \mathrm{Ni}, \mathrm{Cu}$ and $\mathrm{Zn}$ reported in the article of
Pirsaheb et al. (2015) or EU Regulations (in case of Cd and $\mathrm{Pb}$ ). Results of Table 10 indicate that using $130 \mathrm{~g}$ oat grain products per day gives little influence on possibility to achieve a limit of PTWI in the case of $\mathrm{Cd}, \mathrm{Pb}, \mathrm{Cr}, \mathrm{Ni}$ and $\mathrm{Cu}$. In the case of $\mathrm{Zn}$, the calculated $102 \%$ of EWI:PTWI should be significantly lower, if bioavailability of $\mathrm{Zn}$ was taken in account. According to WHO/FAO (2004), in the case of cereal grains the assumed bioavailability for $\mathrm{Zn}$ from cereal grains is $15-30 \%$ only. To evaluate nutritional aspects due to $\mathrm{K}, \mathrm{Na}, \mathrm{Ca}, \mathrm{Mn}, \mathrm{Mg}, \mathrm{Fe}, \mathrm{Cu}, \mathrm{Zn}$ and $\mathrm{Cr}$ concentration in oat grain, the mean concentration was calculated for all 36 samples. Daily consumption was calculated presuming that all grain products $(130 \mathrm{~g})$ consist only of oat products. 
Table 9. The mean concentration, estimated (EWI) and potential tolerable (PTWI) weekly intake of trace elements

\begin{tabular}{|c|c|c|c|c|c|c|c|}
\hline Element & $\mathrm{Cd}$ & $\mathrm{Pb}$ & $\mathrm{Cr}$ & $\mathrm{Ni}$ & $\mathrm{Cu}$ & $\mathrm{Zn}$ & $\mathrm{Al}$ \\
\hline Mean concentration, $\mathrm{mg} \mathrm{kg}^{-1}$ & 0.016 & 0.030 & 0.565 & 1.015 & 3.7 & 28.2 & 5.0 \\
\hline EWI, $\mu \mathrm{g} \mathrm{kg}^{-1}$ of body weight & 0.24 & 0.46 & 8.57 & 15.4 & 56.1 & 428 & 76 \\
\hline PTWI, $\mu \mathrm{g} \mathrm{kg}^{-1}$ of body weight & $2,5^{1}$ & $25^{2}$ & $23.3^{3}$ & $35^{3}$ & $500^{3}$ & $420^{3}$ & $117^{4}$ \\
\hline EWI:PTWI 100\% & 9.6 & 1.8 & 36.8 & 44 & 11.2 & 102 & 65 \\
\hline
\end{tabular}

${ }^{1}$ - EC Regulation No. 488/2014, ${ }^{2}$ - EC Regulation No. 1881/2006; ${ }^{3}$ - Pirsaheb et al., 2015; ${ }^{4}$ - calculated from tolerable daily intake $1 \mathrm{mg} \mathrm{day}^{-1}$ (WHO, 1996)

Table 10. Possible contribution of oat grain in the recommended daily intake of macro elements and $\mathrm{Mn}$

\begin{tabular}{lccccccccc}
\hline & $\mathrm{K}$ & $\mathrm{Na}$ & $\mathrm{Ca}$ & $\mathrm{Mn}$ & $\mathrm{Mg}$ & $\mathrm{Fe}$ & $\mathrm{Cu}$ & $\mathrm{Zn}$ & $\mathrm{Cr}$ \\
\hline Mean concentration, mg kg-1 & 3922 & 75 & 774 & 39.9 & 1377 & 43.9 & 3.7 & 28.2 & 0.565 \\
\hline Recommended intake (mg) by: & & & & & & & \\
Latvian Ministry of Health (LMH) & $4000^{1}$ & $3300^{1}$ & $1000-1200^{1}$ & $3^{2}$ & $350^{1}$ & $10-18^{2}$ & $3^{2}$ & $14^{2}$ & $0.2^{2}$ \\
European Food Safety Authority (EFSA), 2006 & 3000 & 1500 & $900-1200$ & - & 250 & 25 & 5 & 25 & 1 \\
\hline Daily consumption, present work, in: & & & & & & & & \\
mg & 510 & 9.8 & 101 & 5.2 & 179 & 5.7 & 0.48 & 3.7 & 0.073 \\
\% from LMH & 13 & 0.3 & $8-10$ & 173 & 51 & $32-57$ & 16 & 26 & 36.5 \\
\% from EFSA & 17 & 0.7 & $8-11$ & - & 72 & 23 & 10 & 15 & 7 \\
\hline
\end{tabular}

${ }^{1}-2013,^{2}-2014$

The calculated data of consumption were compared with recommendations for daily intake issued by the LMH $(2013 ; 2014)$ and tolerable daily intakes of EFSA (2006). The highest contribution of oat grain in the recommended intake is remarkable in the cases of $\mathrm{Mn}$, $\mathrm{Mg}, \mathrm{Fe}, \mathrm{Zn}$ and $\mathrm{Cr}(173,51,32-57,26$ and $36.5 \%$ from recommendations of LMH, respectively).

\section{Conclusions}

1. Element concentrations in the studied oat grain samples grown in Latvia were mainly similar to those reported by other authors. However, in some cases $(\mathrm{Cd}, \mathrm{Pb}, \mathrm{Cr}, \mathrm{Ni}, \mathrm{Cu}, \mathrm{Na}$ and $\mathrm{K})$ the concentrations were significantly different.

2. The concentrations of $\mathrm{Cr}, \mathrm{Ni}, \mathrm{Zn}, \mathrm{K}$ and $\mathrm{Mg}$ in oat grain differed statistically significantly between the genotypes.

3. Higher $\mathrm{Cd}, \mathrm{Pb}, \mathrm{Ni}, \mathrm{Cu}, \mathrm{Ca}, \mathrm{Mn}$ and $\mathrm{Fe}$ concentrations were determined in oat grain grown conventionally, higher $\mathrm{Cr}, \mathrm{Zn}, \mathrm{Al}, \mathrm{K}, \mathrm{Na}$ and $\mathrm{Mg}$ concentration were in oat grain grown organically. The concentration of $\mathrm{Mn}$ and Fe differed statistically significantly in the organically and conventionally (with different $\mathrm{N}$ supply) grown oat grain.

4. Higher $\mathrm{Cr}, \mathrm{Ni}, \mathrm{Cu}, \mathrm{Al}, \mathrm{Na}$ and $\mathrm{Fe}$ concentrations were in hulled grain ('Lizete'), the concentrations of $\mathrm{Cd}$, $\mathrm{Pb}, \mathrm{Zn}, \mathrm{K}, \mathrm{Ca}, \mathrm{Mn}$ and $\mathrm{Mg}$ were higher in naked grain (No. 33793 and 'Stendes Emilija'). The concentration of $\mathrm{Cr}, \mathrm{Ni}, \mathrm{Zn}, \mathrm{K}, \mathrm{Na}$ and $\mathrm{Mg}$ differed statistically significantly in hulled and naked grain.

5. The concentration of $\mathrm{Cd}, \mathrm{Pb}, \mathrm{Ni}, \mathrm{Cu}, \mathrm{Al}, \mathrm{K}$, $\mathrm{Na}$ and $\mathrm{Mg}$ in oat grain differed statistically significantly between the study years.

6. The concentrations of potentially hazardous elements were low: $\mathrm{Cd} 0.008-0.023, \mathrm{~Pb} 0.014-0.060$, $\mathrm{Cr} 0.117-1.460, \mathrm{Ni} 0.447-1.834, \mathrm{Cu} 3.2-4.1$ and $\mathrm{Zn}$ $22.0-32.3 \mathrm{mg} \mathrm{kg}$. Oat products can contribute to the consumption of necessary macro and trace elements, especially $\mathrm{Mn}, \mathrm{Mg}$ and Fe: $30.0-49.3,1166-1486$ and $33.5-48.9 \mathrm{mg} \mathrm{kg}^{-1}$, respectively, as well as $\mathrm{Cr}$ and $\mathrm{Zn}$.

\section{Acknowledgments}

The authors acknowledge financial support from the European Social Fund project No. 2013/0072/1DP/ 1.1.1.2.0/13/APIA/VIAA/032.

Received 16042018 Accepted 26112018

\section{References}

1. ATSDR. 2005. Public Health Assessment Guidance Manual. Appendix G: Calculating Exposure Doses. https:// www.atsdr.cdc.gov/hac/phamanual/appg.html

2. Bleidere M., Vīcupa Z., Zute S. 2012. Food grain quality traits in oat under organic and conventional growth conditions. Safe Food. Proceedings of $16^{\text {th }}$ International Eco-Conference. Novi Sad, Serbia, p. 353-360.

3. Brunava L., Vilmane L., Zute S. 2015. Influence of nitrogen application rate and meteorological conditions on $\beta$-glucan content in naked and husked oat grains. Proceedings of the Latvian Academy of Sciences, 69 (4): 178-181. https://doi.org/10.1515/prolas-2015-0026

4. Chapell A., Scott K. P., Griffiths I. A., Cowan A. A., Hawes C., Wishart J., Martin P. 2017. The agronomic performance and nutritional content of oat and barley varieties grown in a northern maritime environment depends on variety and growing conditions. Journal of Cereal Science, 74: 1-10. https://doi.org/10.1016/j.jcs.2017.01.005

5. CSB. 2015. Central Statistical Bureau of the Republic of Latvia. Consumption of food products average per household member per year (ECOICOP), 2016. http://data1.csb.gov.lv/ pxweb/en/sociala/sociala mb paterins/MBG161.px

6. Demirbas A. 2005. $\beta$-Glucan and mineral nutrient contents of cereals grown in Turkey. Food Chemistry, 90: 773-777. https://doi.org/10.1016/j.foodchem.2004.06.003

7. EFSA. 2006. European Food Safety Authority. Tolerable upper intake levels for vitamins and minerals. Scientific Committee of Food/Scientific Panel of Dietetic Products, Nutrition and Allergies, 478 p. http://www.efsa.europa.eu/sites/default/files/ efsa rep/blobserver assets/ndatolerableuil.pdf

8. Ekhōlm P., Reinivuo H., Mattila P., Pakkala H., Koponen J., Happonen A., Hellström J., Ovaskainen M.-L. 2007. Changes in the mineral and trace element contents of cereals, fruit and vegetables in Finland. Journal of Food Composition and Analysis, 20: 487-495. https://doi.org/10.1016/j.jfca.2007.02.007

9. EU. 2017. EU Cereals balance sheet $2016 / 17$ and forecast 2017/18. Committee for the Common Organisation of Agricultural Markets. https://ec.europa.eu/agriculture/ sites/agriculture/files/cereals/presentations/-oilseeds/ balance-sheets-and-forecasts en.pdf

10. Graham R., Welch R., Bouis H. 2001. Addressing micronutrient malnutrition through the nutritional quality of staple foods: Principles, perspectives, and knowledge gaps. Advances in Agronomy, 70: 77-142. https://doi.org/10.1016/S0065-2113(01)70004-1

11. Hirel B., Tetu T., Lea P. J., Dubois F. 2011. Improving nitrogen use efficiency in crops for sustainable agriculture. Sustainability, 3 (9): 1452-1485. https://doi.org/10.3390/su3091452

12. Jākobsone I., Kantāne I., Zute S., Jansone I., Bartkevičs V. 2015. Macro-elements and trace elements in cereal grains cultivated in Latvia. Proceedings of the Latvian Academy of Science, Section B, 69 (4): 152-157. https://doi.org/10.1515/prolas-2015-0022 
13. Korkmaz K., Kara S. M., Ozkutlu F., Gul V. 2010. Monitoring of heavy metals and selected micronutrients in hempseeds from north-western Turkey. African Journal of Agricultural Research, 5: 463-467.

14. LMH. 2013. Ministry of Health of the Republic of Latvia. Healthy food, microelements. http://www.vm.gov.lv/lv/ tava veseliba/veseligs uzturs/mikroelementi/ (in Latvian).

15. LM $\bar{H}$. 2014. Ministry of health of the Republic of Latvia. Healthy food, mineral substances. http://www.vm.gov.lv/ lv/tava_veseliba/veseligs_uzturs/mineralvielas/(in Latvian).

16. Lui K., Peterson K. L., Raboy V. 2007. Comparison of the phosphorus and mineral concentrations in bran and abraded kernel fractions of a normal barley (Hordeum vulgare) cultivar versus four low phytic acid isolines. Journal of Agricultural and Food Chemistry, 55 (11): 4453-4460. https://doi.org/10.1021/jf0637776

17. Martínez-Villaluenga C., Peñas E. 2017. Health benefits of oat: current evidence and molecular mechanisms. Current Opinion in Food Science, 14: 26-31. https://doi.org/10.1016/j.cofs.2017.01.004

18. Pirsaheb M., Fattahi N., Sharafi K., Khamotian R., Atafar Z. 2015. Essential toxic heavy metals in cereals and agricultural products marketed in Kermanshah, Iran, and human health risk assessment. Food Additives and Contaminants. Part B, 9 (1): 15-20. https://doi.org/10.1080/19393210.2015.1099570

19. Poutanen K. 2012. Past and future of cereal grains as food for health. Trends in Food Science and Technology, 25: 58-62. https://doi.org/10.1016/j.tifs.2012.02.003

20. Reinholds I., Pugajeva I., Bavrins K., Kuckovska G., Bartkevics V. 2017. Mycotoxins, pesticides and toxic metals in commercial spices and herbs. Food Additives and Contaminants. Part B, 10 (1): 5-14. https://doi.org/10.1080/19393210.2016.1210244

21. Rybicka I., Gliszczyńska-Świgło A. 2017. Minerals in grain gluten-free products. The content of calcium, potassium, magnesium, sodium, cooper, iron, manganese, and zinc. Journal of Food Composition and Analysis, 59: 61-67. https://doi.org/10.1016/j.jfca.2017.02.006
22. Sahlstrom S., Knutsen S. H. 2010. Oats and rye: production and usage in Nordic and Baltic countries. Cereal Food World, 55 (1): 12-14. https://doi.org/10.1094/CFW-55-1-0012

23. Sterna V., Zute S., Brunava, L., Vicupe Z. 2014. Lipid composition of oat grain grown in Latvia. Proceedings of Baltic Conference on Food Science and Technology FOODBALT, p. 77-80.

24. Sterna V., Zute S., Jansone I., Brunava L., Kantane I. 2015 (a). The chemical composition of new oat varieties and breeding lines created in Latvia. Acta Biologica Universitatis Daugavpiliensis, 15 (2): 367-373.

25. Sterna V., Zute S., Jansone I., Brunava L., Kantane I. 2015 (b). Oat grain functional ingredient characterization, World Academy of Science, International Journal of Agricultural and Biosystems Engineering, 9 (7): 791-794.

26. Sterna V., Zute S., Brunava L. 2016. Oat grain composition and its nutritional benefice. Agriculture and Agricultural Science Procedia, 8: 252-256.

https://doi.org/10.1016/j.aaspro.2016.02.100

27. Teklić T., Lončarić Z., Kovačević V., Singh B. R. 2013. Metallic trace elements in cereal grain - a review: how much metal do we eat? Food and Energy Security, 2 (2): 81-85. https://doi.org/10.1002/fes3.24

28. Vilmane L., Zute S., Straumite E., Galoburda R. 2015. Protein, amino acid and gluten content in oat (Avena sativa L.) grown in Latvia. Proceedings of the Latvian Academy of Sciences, 69 (4): 170-177. https://doi.org/10.1515/prolas-2015-0025

29. WHO. 1996. Trace Elements in Human Nutrition and Health, 343 p. http://apps.who.int/iris/handle/10665/37931

30. WHO/FAO. 2004. Vitamin and mineral requirements in human nutrition ( $2^{\text {nd }}$ ed.). WHO and FAO, 341 p. http://apps. who.int/iris/bitstream/10665/42716/1/9241546123.pdf

31. Xin-Zhong H., Jian-Mei Z., Xiao-ping L., Chao X., Qiong Z. 2014. Chemical composition and sensory characteristics of oat flakes: a comparative study of naked oat flakes from China and hulled oat flakes from western countries. Journal of Cereal Science, 60 (2): 297-301.

https://doi.org/10.1016/j.jcs.2014.05.015

32. Zute S., Vicupe Z., Gruntina M. 2010. Factors influencing oat grain yield and quality under growing conditions of West Latvia. Agronomy Research, 8: 749-754.

ISSN 1392-3196 / e-ISSN 2335-8947

Zemdirbyste-Agriculture, vol. 106, No. 1 (2019), p. 21-28

DOI $10.13080 / \mathrm{z}-\mathrm{a} .2019 .106 .003$

\title{
Makro- ir mikroelementų kiekis Latvijoje išvestų veislių avižose
}

\author{
I. Jakobsone', S. Zute'2, M. Bleidere², I. Kantane², L. Ece ${ }^{1,2}$, V. Bartkevics ${ }^{4}$ \\ ${ }^{1}$ Latvijos universiteto Chemijos fakultetas \\ ${ }^{2}$ Žemès ūkio resursų ir ekonomikos instituto (AREI) Stende tyrimų centras, Latvija \\ ${ }^{3}$ Latvijos universiteto Verslo, vadybos ir ekonomikos fakultetas \\ ${ }^{4}$ Maisto saugos, gyvūnų sveikatos ir aplinkos institutas (BIOR), Latvija
}

\section{Santrauka}

Tyrimo metu siekta nustatyti trylikos makro- ir mikroelementų kiekị ịvairiuose sejjamosios avižos (Avena sativa L.) genotipuose, priklausomai nuo auginimo metų (2011, 2012 ir 2013), auginimo sistemos (tradicinès bei ekologinès) ir taikytų agrotechnikos priemonių (skirtingo aprūpinimo azotu $(\mathrm{N})$ ), taip pat įvertinti riziką, susijusią su cheminių elementų $\mathrm{Cd}, \mathrm{Pb}, \mathrm{Cr}, \mathrm{Ni}, \mathrm{Cu}, \mathrm{Zn}$ bei Al koncentracijomis avižų grūduose, ir mitybinius $\mathrm{K}, \mathrm{Na}, \mathrm{Ca}, \mathrm{Mn}, \mathrm{Mg}$, $\mathrm{Fe}, \mathrm{Cu}, \mathrm{Zn}$ bei $\mathrm{Cr}$ koncentracijos avižų grūduose aspektus. Elementų $\mathrm{Cd}, \mathrm{Pb}, \mathrm{Cr}$, Ni ir Al kiekiai buvo nustatyti elektrotermine atominés absorbcijos spektrometrija, o K, Na, $\mathrm{Zn}, \mathrm{Cu}, \mathrm{Ca}, \mathrm{Mg}, \mathrm{Mn}$ ir Fe kiekiai buvo tirti taikant atominę absorbcijos spektrometriją. Klasterinè analizè parodè, kad makro- ir mikroelementu kaupimuisi avižu grūduose didelę reikšmę turi genotipas, auginimo sistema ir taikytos agrotechnikos priemonès. Nustatyta $\mathrm{Cr}, \mathrm{Ni}$, $\mathrm{Zn}, \mathrm{K}$ ir Mg koncentracijų esminiai skirtumai tarp genotipų: $\mathrm{Mn}$ ir Fe skirtumai grūduose, augintuose tradiciškai ir ekologiškai, Cr, Ni, Zn, K ir Mg skirtumai tarp avižų su lukštais ir be lukštų grūdų ir $\mathrm{Cd}, \mathrm{Pb}, \mathrm{Ni}, \mathrm{Cu}, \mathrm{Al}, \mathrm{K}, \mathrm{Na}$ bei $\mathrm{Mg}$ skirtumai tarp tyrimų metų. Potencialiai žalingų elementų koncentracijos buvo mažos: $\mathrm{Cd} 0,008-0,023, \mathrm{~Pb}$ 0,014-0,060, Cr 0,117-1,460, Ni 0,447-1,834, Cu 3,2-4,1 ir Zn 22,0-32,3 mg kg-1. Vartojant iš avižų pagamintus produktus mitybą galima papildyti būtinais makro- ir mikroelementais, ypač Mn, Mg ir Fe, atitinkamai 30,0-49,3, $1166-1486$ ir 33,5-48,9 $\mathrm{mg} \mathrm{kg}^{-1}$, taip pat ir Cr bei Zn.

Reikšminiai žodžiai: Avena sativa, ekologinė žemdirbystè, makro- ir mikroelementai, mitybiniai aspektai, rizikos ivvertinimas, statistiniai rodikliai, tradicinis ūkininkavimas. 